\title{
Fenomenologi Kampanye Politik Pada Pilkada Jawa Timur
}

\author{
Fatmawati \\ Dosen Fakultas Ilmu Komunikasi Universitas Islam Riau \\ fatmakaffa@gmail.com
}

\begin{abstract}
Purpose of research to explain political campaign of experience's KarSa Success Team in East Java election for twice period. East Java election to be one of election with interested to studied, because of this election have to more specially, about candidate and competition to be winner with political campaign. KarSa's Winning were result of exploration to political campaign's concept approach local wisdom to be done in firts period and second period. This study uses qualitative research with phenomenological approach. Phenomenologically of research was an approach interpretif subjective wich to exploration's experiences This Research are explores the subjective experience's team success in conducting political campaigns in the Eastjava election. There are five Informants, were selected using purposive. Data were analyzed using the phenomenological analysis techniques to find important themes and make models of the research. The results of this study that the experience's political campaign by Success Team KarSa used to 5M of local wisdom concept. 5M of concept practice to "Sambang Desa" programm. It's consist of $3 M$ (to eye, to ear, and to feel) for each problem in village. After $3 M$, continued with $2 M$ (to arrange and to practice). Meaning of $5 M$ by Team Succsess's experiences in East Java Election as politics education, demokratic practice and persuasive behaviour to society.
\end{abstract}

\section{Keyword : Political Campaign, East Java and Phenomenology.}

\begin{abstract}
ABSTRAK
Penelitian ini bertujuan mengeksplorasi pengalaman kampanye politik Tim Sukses KarSa pada Pilkada Jatim selama dua periode kemenangan. Pilkada Jawa Timur menjadi salah satu momen pilkada yang menarik untuk diteliti, karena kontestasi ini memiliki beragam keunikan, baik dari peserta pilkada maupun persaingan memperebutkan kursi Jatim I melalui kampanye politik. Kemenangan KarSa adalah hasil eksplorasi konsep kampanye politik local wisdom yang konsisten dilakukan, baik pada periode pertama maupun kedua. Penelitian ini menggunakan metode kualitatif dengan pendekatan fenomenologi. Penelitian fenomenologi adalah pendekatan penelitian subyektif interpretif yang diperoleh dari pengalaman langsung subyek informan. Dalam penelitian ini, informan terdiri dari lima orang narasumber yang ditentukan secara purposive sampling. Hasil penelitian mengungkapkan bahwa pengalaman kampanye politik yang dilakukan oleh tim sukses KarSa adalah konsep kampanye politik 5M sebagai konsep local wisdom. Konsep 5M dilakukan melalui program "Sambang Desa". Sambang desa terdiri dari 3M (melihat, mendengar dan merasakan) setiap permasalahan yang muncul di desa-desa. Setelah 3M, Tim KarSa melanjutkan program 2M yakni (menyusun dan melaksanakan). Makna kampanye politik 5M yang dilakukan oleh Tim Sukses KarSa pada Pilkada Jatim adalah sebagai
\end{abstract}


bentuk pendidikan politik, perwujudan demokrasi, dan tindakan persuasi kepada masyarakat.

\section{Kata Kunci : Kampanye Politik, Pilkada dan Fenomenologi}

\section{PENDAHULUAN}

Pilkada (Pemilihan Kepala

Daerah) merupakan mekanisme pemilihan secara langsung pemimpin eksekutif di daerah, mulai dari Walikota, Bupati, hingga Gubernur. Pemilihan kepala daerah secara langsung ini merupakan konsekuensi dari tuntutan demokratis yang dilakukan di era-reformasi dalam rangka memilih pemimpin daerah yang benar-benar sesuai dengan harapan masyarakat. Pencalonan kepala daerah dapat diusulkan oleh partai politik atau gabungan parpol secara berpasangan dengan persyaratan yang diatur dalam Undang-undang. Selain itu juga dapat melalui jalur independen yang jumlah pendukungnya dapat ditunjukkan melalui KTP (Kartu Tanda Penduduk).

Jawa Timur sebagai salah satu provinsi di Indonesia, telah beberapa kali melaksanakan pilkada secara langsung. Pilkada Jawa Timur juga telah mencatat sejarah terpanjang dalam pelaksanaannya karena pilkada digelar dalam tiga kali putaran. Keunikan juga berlanjut pada pelaksanaan pilkada Jatim 2013. Para pengamat politik menduga pertarungan sengit bakal terjadi pada pilkada ini karena incumbent turut berpartisipasi kembali melawan rival terberatnya dalam pilkada 2008 .
KarSa sebagai pemenang pada dua kali Pilkada Jawa Timur, yakni periode 2008-2013 dan 2013-2018. Soekarwo dan Saifullah Yusuf maju kembali dengan tetap berpasangan menjadi kandidat Gubernur dan Wakil Gubernur Jawa Timur. KarSa memiliki tim sukses yang solid dan profesional, terbukti mampu mengantarkan pada kemenangan dua periode.

$$
\text { Penelitian ini berusaha }
$$

memperoleh pengalaman langsung kampanye politik Tim Sukses KarSa dalam memenangkan Pilkada Jawa Timur selama dua periode. Pertanyaan penelitian yang dijawab dalam penelitian ini ada dua yakni: bagaimana pengalaman kampanye politik Tim Sukses KarSa? Apa makna komunikasi politik yang dilakukan oleh Tim Sukses KarSa?

Adapun manfaat dari penelitian ini adalah: dari aspek ontologis, sebagai referensi untuk kajian pengembangan dalam ilmu komunikasi yang berkaitan dengan komunikasi politik (politicalcommunication); dari aspek epistemologis, penelitian ini untuk memperoleh pengalaman secara sadar terkait kampanye politik yang dilakukan oleh tim sukses KarSa dalam memenangkan Pilkada Jatim dan makna yang terkandung didalam kampanye politik yang dilakukan tersebut. Sedangkan dari aspek aksiologis, 
penelitian ini memberikan kontribusi konstruktif bagi pelaksanaan kampanye politik dalam pelaksanaan demokrasi yang ideal yaitu membawa aspirasi dan memprioritaskan kepentingan rakyat.

\section{KERANGKA PEMIKIRAN}

\section{Kampanye Politik}

Kampanye yang dimaksud dalam kajian Ilmu Komunikasi adalah penyebarluasan informasi atau ide atau gagasan. Herbert Siemens menyebutkan Campaign is organized of people thrught a series of message (kampanye adalah kegiatan terorganisasi oleh orang-orang yang melalui serangkaian pesan). William Paisley menyebutkan, campaign or communication campaign are only means of influencing public knowledge, attitude, and behavior (kampanye atau kampanye komunikasi dapat diartikan mempengaruhi pengetahuan publik, sikap dan prilaku publik) (Rice dan Paisley, 1981: 23).

Sedangkan dalam konteks komunikasi politik, kampanye dimaksudkan untuk memobilisasi dukungan terhadap suatu hal atau seorang kandidat. "political campaigns are aimed at the mobilization of support for one's cause or candidate" (Steven Chaffe dalam Changara, 2014: 223). Definisi Kampanye yang paling populer adalah yang dikemukakan oleh Rogers dan Storey (1987) yaitu "serangkaian tindakan komunikasi yang terencana dengan tujuan untuk menciptakan efek tertentu pada sejumlah besar khalayak yang dilakukan secara berkelanjutan pada kurun waktu tertentu (Venus, 2009: 7).

Merujuk pada definisi ini maka setiap aktivitas kampanye komunikasi setidaknya harus mengandung empat hal yakni: (1) tindakan kampanye yang ditujukan untuk menciptakan efek atau dampak tertentu, (2) jumlah khalayak sasaran yang besar (3) biasanya dipusatkan dalam kurun waktu dan (4) melalui serangkaian tindakan komunikasi yang terorganisasi. Disamping keempat hal tersebut kampanye juga memiliki karakter yaitu sumber jelas yang menjadi penggagas, perancang, penyampai sekaligus penanggungjawab suatu produk kampanye, sehingga setiap individu yang menerima pesan kampanye dapat mengindentifikasi bahkan mengevaluasi kredibilitas sumber pesan tersebut setiap saat. (Venus, 2009:7).

Dari berbagai sumber yang mengemukakan perihal kampanye dapat disimpulkan bahwa kegiatan kampanye (terkait kampanye politik dalam penelitian ini) adalah upaya persuasif penyampaian ide/gagasan terbaik yang diorganisasi untuk memperoleh dukungan publik. Oleh karena itu setiap kegiatan kampanye politik hendaknya dilakukan dengan cara yang baik dan simpatik, karena tujuan kampanye adalah untuk merebut hati publik agar dapat menerima ide/gagasan yang disampaikan komunikator (baik Partai politik maupun calon Kepala Daerah).

Pilkada Jawa Timur 
Pemilihan Kepala Daerah atau disingkat Pilkada menjadi momen menarik di setiap daerah karena hajat besar ini akan melahirkan pemimpin daerah yang nantinya dapat membawa daerah ke arah lebih baik. Provinsi Jawa Timur telah mengalami pergantian Gubernur sebanyak 13 kali. Soekarwo dan Saifullah Yusuf (KarSa) adalah pasangan Gubernur dan Wakil Gubernur Jawa Timur ke-12 dan 13.

Sejarah pelaksanaan Pilkada menjadi lebih menarik karena sejak 2008, Pilkada di Jawa Timur dilakukan secara langsung. Ini menjadi tugas berat buat para politisi yang berkeinginan menjadi calon pemimpin di Jawa Timur. Jika sebelumnya, Pilkada diwarnai negosiasi dan lobby kepada anggota legislatif sebagai penentu kepala daerah, maka sejak dilakukannya Pilkada secara langsung, para calon Gubernur dan wakil Gubernur harus giat melakukan komunikasi kepada warga masyarakat yang akan memilih secara langsung calon pemimpin tersebut.

Pemilihan Gubernur Jawa Timur 2008 merupakan pemilihan Gubernur secara langsung pertama kali bagi warga Jawa Timur. Masyarakat Jawa Timur memang sudah memiliki pengalaman mengikuti pemilu langsung yakni Pemilu legislatif 2004. Beberapa kabupaten juga menyelenggarakan pemilihan kepala daerah kabupaten/kota pada 2005 - 2006. Meski sama-sama pemilihan langsung namun terdapat perbedaan proximity (kedekatan) politik antara memilih presiden dan bupati/walikota dengan Gubernur, sebab masyarakat pemilih merasa tak pernah bersentuhan langsung dengan kebijakan-kebijakan pemerintah provinsi.

Rendahnya proximity politik ini memengaruhi antusiasme politik masyarakat untuk berpartisipasi dalam pemilihan Gubernur, juga terdapat kepedulian mereka mengenali kontestan beserta produk politiknya. Itu artinya, untuk memenangi pemilihan Gubernur -disamping cukup populer di kalangan masyarakat pemilih- kandidat juga harus mampu membangkitkan greget politik mereka untuk peduli dan bersedia berpartisipasi dalam pemilihan Gubernur Jawa Timur.

\section{Tujuan Penelitian}

Merujuk pada rumusan permasalahan dalam penelitian ini, maka tujuan penelitian ini terdiri dari dua yakni:

1. Untuk mengeksplorasi pengalaman kampanye politik tim sukses KarSa pada Pilkada Jawa Timur.

2. Untuk menjelaskan tentang makna kampanye politik yang dilakukan oleh tim sukses KarSa pada Pilkada Jawa Timur.

\section{Metode Penelitian}

Untuk mengungkap dan menjelaskan tentang makna Kampanye Politik oleh Tim Sukses KarSa pada Pilkada Jatim digunakan metode kualitatif dengan pendekatan fenomenologi. Metode kualitatif dengan 
Pendekatan fenomenologi bertumpu pada pemahaman terhadap pengalaman subyektif atas gejala alamiah (fenomena) atau peristiwa dan kaitankaitannya. Subyek penelitian ini terdiri dari lima orang yang merupakan tim sukses KarSa pada periode I dan II, dilakukan dengan menggunakan purposive sampling. Teknik analisis data yang digunakan dalam penelitian ini adalah dengan menggunakan teknik analisis fenomenologi. Metode fenomenologi yang digunakan adalah fenomenologi Hermeneutik dari Heidegger yang lebih berorientasi pada pencarian makna pengalaman bagi subyek. Pada penelitian ini menggunakan empat bentuk pemaparan, yakni: Horizontalisasi, penyajian pernyataan penting (significant statements), analisis tema, dan reduksi fenomenologis atau pernyataan esensi pengalaman.

\section{Hasil Penelitian dan Pembahasan \\ Pengalaman Kampanye Politik KarSa}

Berdasarkan hasil analisis terhadap data wawancara kepada lima informan, peneliti mengelompokkan kedalam dua bagian sesuai dengan pertanyaan penelitian ini, yakni: Pengalaman kampanye politik tim KarSa dalam memenangkan pilkada jatim dan bagaimana tim sukses memaknai kampanye politik tersebut.

Untuk pertanyaan pertama terkait dengan pengalaman kampanye politik tim sukses pada pilkada Jatim, informan MR mengatakan:
"Kuncinya ada di desa, kami menyebutnya sambang desa. program inilah yang mengantarkan kami pada kemenangan dua periode. Di era sekarang orang menyebutnya blusukan. Itu sudah kami lakukan jauh sebelumnya... ," (wawancara MR, 29 Juli 2016).

Pengalaman kampanye politik KarSa dilakukan dengan melakukan kunjungan ke berbagai pelosok desa. Tim sukses menyebutnya dengan program "Sambang Desa". Program sambang desa adalah sebuah program yang digagas oleh tim sukses KarSa selama dua periode, program ini menjadi program andalan dalam kampanye politik yang dilakukan KarSa ke masyarakat. MR adalah ketua Tim Sukses KarSa Jilid I. MR mengakui bahwa pengalaman kampanye politik KarSa dimulai jauh sebelum pelaksanaan proses pemilihan dilakukan, sejak 2004. Tim sukses sudah mulai bergerilya menyusun dan melakukan kampanye politik ke berbagai elemen masyarakat. Informan YS juga mengatakan hal yang senada:

"Tim sudah mulai dari 2004, kita turun ke desa. Melihat, Mendengar dan Merasakan secara langsung apa yang dialami oleh masyarakat. kita duduk bareng di warung kopi, bahkan tak jarang juga menginap disana untuk mengetahui kondisi masyarakat yang sesungguhnya. Apa yang mereka perlukan, apa yang sedang menjadi masalah utama mereka. Pak de itu sangat telaten, melakukan itu dengan hati tulus, tidak dibuat-buat...", 
(Wawancara YS, 22 September 2016).

YS menerangkan bahwa kampanye politik sambang desa ini yang akan dibuat untuk visi, misi dan program KarSa baik di jilid pertama maupun kedua. Konsep itu terdiri dari 3 M (Melihat, mendengar dan Merasakan) secara langsung apa yang terjadi di masyarakat. YS mengakui menjadi tim utama penyusun program melalui Sambang Desa.

Pengalaman kampanye politik yang dilakukan oleh TN dan AN adalah sebagai berikut:

"Rencana itu dimulai dengan 3M: melihat, mendengar, dan merasakan. Kami datang mengunjungi warga di desa, melihat akar permasalahan sebenernya. Opo seng dikarepno masyarakat itu kita lihat, dirungokno lalu kemudian kita jadi tahu dan merumuskannya melalui program sambang desa. Itu efektif sekali, mbak. Makanya program sambang desa itu adalah hasil kerja nyata yang tidak dibuat-buat....

(Wawancara TN, 25 Agustus 2016).

Lebih lanjut informan AN mengatakan hal senada:

"Mengkomunikasikan janji
politik ke masyarakat itu
sesungguhnya tidak mudah.
Coba mbak lihat, tidak sedikit
masyarakat yang apatis ke
urusan politik ini karena pesan
politik yang dibawa sama.
Semua sama, kemiskinan,
pendidikan, pengangguran,
layanan masyarakat. karena itu

kami melakukan ini dengan niat tulus, kami datang langsung dan mendengar permasalahan mereka. 5M itu menjadi acuan kerja kami, tidak ngarangngarang. Visi misi itu hasil need assesment kondisi masyarakat yang sesungguhnya... (Wawancara AN, 10 Juli 2016).

Menurut AN, banyak pesan politik yang disampaikan politisi kepada masyarakat cenderung paritas. Permasalahan dasar yang dialami masyarakat diberbagai daerah hampir merupakan kondisi yang serupa namun AN mengatakan bahwa yang menjadikan keunikan dari strategi sambang desa ini adalah program itu merupakan hasil curhatan masyarakat yang murni dari hasil identifikasi melalui program 5M yang digagas Tim Sukses KarSa. Program sambang desa ini konsisten dilakukan dalam dua periode kemenangan KarSa. Wujud nyata dari program sambang desa ini dituangkan dalam kegiatan yang disebut Cangkrukan dan Jajah Desa Milangkori. Cangkrukan, yakni budaya duduk-duduk santai di depan rumah warga atau warung kecil di desa yang sifatnya sangat informal. Dalam Cangkrukan ini, Soekarwo seringkali hanya datang berdua dengan anggota tim sukses dan tanpa pemberitahuan terlebih dahulu. Sedangkan Jajah Desa Milangkori, merupakan bagian dari program Sambang Desa. Hanya program ini lebih terencana dan sering kali Soekarwo datang dengan beberapa anggota tim sukses dan pejabat 
pemerintah Provinsi (karena juga sebagai salah satu bagian program pemerintah provinsi yang bertujuan sebagai sarana komunikasi pemerintah daerah dengan masyarakat). Pada periode kedua, sambang desa dilakukan pada setiap Sabtu dan Minggu yakni hari libur kerja. Selain dua kegiatan sambang desa (Cangkrukan dan Jajah Desa Milangkori, Tim sukses juga sering mengadakan diskusi baik skala kecil maupun besar dan seminarseminar).

Model kampanye politik yang tertuang dalam Sambang desa ini adalah merupakan wujud komunikasi dialogis. Bentuk komunikasi ini memberikan peluang yang lebih besar kepada publik untuk mengetahui secara langsung bagaimana visi, misi, dan program kandidat. Model kampanye politik ini terus dilakukan baik pada KarSa I maupun KarSa II. Pada KarSa II model ini dilakukan sebagai upaya menggali informasi terkait visi, misi, dan program yang sudah dijalankan pada periode KarSa I. Pasangan Kandidat dan Tim
Sukses berusaha mengadakan dialog ke berbagai elemen masyarakat untuk mendapatkan informasi bagaimana implementasi dari visi, misi, dan program kemudian meminta masyarakat untuk memberi masukan (evaluasi) kepada tim. Langkah ini dilakukan sebagai upaya untuk menformulasikan kembali visi, misi, dan program yang ada di KarSa I.

Informan $\mathrm{TN}$ yang merupakan ketua Tim Sukses KarSa II mengatakan bahwa pada periode kedua KarSa, tim sukses tidak lagi bekerja berat seperti yang dilakukan oleh Tim Sukses KarSa I. Tim Sukses melanjutkan program yang sama dengan program KarSa I. Strategi sambang desa terus dilakukan untuk berkomunikasi secara langsung kepada masyarakat. Ide dasar dari visi, misi dan program KarSa I dan II adalah sama, berorientasi pada APBD rakyat yang dituangkan melalui berbagai program pro rakyat. Berikut adalah visi, misi, program, tujuan dan slogan dari KarSa I dan II:

Tabel 1.

Visi, Misi, Tujuan, dan Slogan KarSa I dan II

\begin{tabular}{|c|c|c|}
\hline & KarSa I & KarSa II \\
\hline Visi & 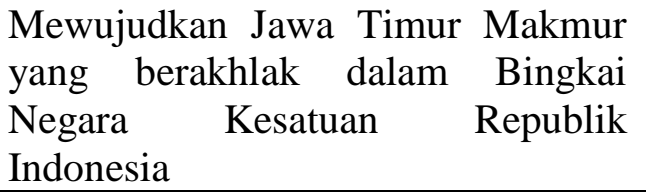 & $\begin{array}{l}\text { Mewujudkan masyarakat Jawa } \\
\text { Timur yang sejahtera, berakhlak dan } \\
\text { berdaya saing }\end{array}$ \\
\hline Misi & $\begin{array}{l}\text { APBD untuk rakyat } \\
\text { 1. meningkatkan aksebilitas } \\
\text { pelayanan pendidikan yang } \\
\text { murah dan bermutu } \\
\text { 2. meningkatkan aksebilitas } \\
\text { pelayanan kesehatan yang murah } \\
\text { dan memadai } \\
\text { 3. perluasan lapangan kerja } \\
\text { 4. memberdayakan perekonomian }\end{array}$ & $\begin{array}{l}\text { APBD untuk rakyat } \\
\text { 1. APBD untuk kepentingan } \\
\text { langsung masyrakat diberbagai } \\
\text { bidang meliputi: pendidikan, } \\
\text { kesehatan, penyediaan lapangan } \\
\text { kerja, rekonstruksi lingkungan } \\
\text { hidup } \\
\text { 2. Pengembangan demokrasi } \\
\text { partispatoris dengan }\end{array}$ \\
\hline
\end{tabular}

Jurnal Communication Volume 9 Nomor 1 April 2018 


\begin{tabular}{|l|l|l|}
\hline & $\begin{array}{l}\text { rakyat } \\
\text { 5. memelihara kualitas lingkungan } \\
\text { hidup }\end{array}$ & $\begin{array}{l}\text { meningkatkan partispasi } \\
\text { masyrakat dalam berbagai isu } \\
\text { pembangunan. }\end{array}$ \\
$\begin{array}{l}\text { 6. mewujudkan reformasi birokrasi } \\
\text { 7. peningkatan pelayanan publik } \\
\text { 8. meningkatkan kualitas kesalehan } \\
\text { sosial }\end{array}$ & $\begin{array}{l}\text { 3. Harmonisasi kehidupan } \\
\text { masyarakat yang pluralis } \\
\text { 4. Pembenahan layanan publik }\end{array}$ \\
\hline Tujuan & $\begin{array}{l}\text { Kesejahteraan seluruh rakyat Jawa } \\
\text { Timur }\end{array}$ & $\begin{array}{l}\text { Kesejahteraan dan Kemandirian } \\
\text { Masyarakat Jawa Timur }\end{array}$ \\
\hline Program & $\begin{array}{l}\text { Jalin Kesra (Jalan Lain Menuju } \\
\text { Sejahtera) }\end{array}$ & $\begin{array}{l}\text { Jalan Lain Menuju Jawa Timur } \\
\text { Mandiri dan Sejahtera (Jalin Matra) }\end{array}$ \\
\hline "Makmur bersama Wong Cilik" & $\begin{array}{l}\text { Tuku kripik digawe riyoyo - barang } \\
\text { wes apik ayo diterusno (beli keripik } \\
\text { dibuat lebaran - apa yang baik mari } \\
\text { dilanjutkan) }\end{array}$ \\
\hline
\end{tabular}

Sumber: Tim Sukses KarSa, 2016.

Berdasarkan Tabel 1 diatas dapat dilihat bahwa tidak ada perbedaan mendasar antara KarSa I dan KarSa II. Misi masih berorientasi pada APBD untuk rakyat. Sedangkan Visi, tujuan, program dan slogan KarSa II merupakan penyempurnaan KarSa I. Tim sukses mengakui bahwa pondasi awal kesuksesan KarSa terletak pada perencanaan KarSa I. Perencanaan telah dilakukan dalam rentang waktu yang cukup lama sebelum masa pencalonan dimulai. Sedangkan pada saat KarSa II, hanya mengevaluasi dan melanjutkan program yang sudah berjalan dan sukses pada Karsa I. Tim Sukses KarSa juga tidak mengalami banyak perubahan. Ada pergantian ketua tim sukses namun secara keseluruhan tidak mengalami perubahan. Misalnya pada tim sukses I, ketua dipegang oleh MR, sedangkan ketua KarSa II adalah TN. Namun MR masih menjadi penasehat utama tim sukses KarSa II. Menurut tim sukses KarSa, kesuksesan tim Sukses KarSa juga sangat ditentukan oleh peran kandidat yang merupakan representasi dari semua pesan politik yang tertuang dalam visi, misi, tujuan, program dan slogan yang dibuat. Pasangan kandidat merupakan orang yang tepat mengomunikasikan pesan politik tersebut karena merupakan hasil $5 \mathrm{M}$ yang dirancang dan dilakukan bersama. Soekarwo adalah sosok laki-laki Jawa Tulen yang berasal dari masyarakat desa dan mengerti kondisi desa seutuhnya. Sedangkan Saifullah Yusuf adalah representasi dari masyarakat jawa yang mayoritas religius, berasal dari latar belakang keluarga pesantren yang fanatik dalam menjalankan nilainilai keagamaan. Dua pribadi yang berbeda ini saling melengkapi satu sama lain.

Berikut peneliti gambarkan pengalaman kampanye politik Tim Sukses KarSa pada Pilkada Jawa Timur adalah: 


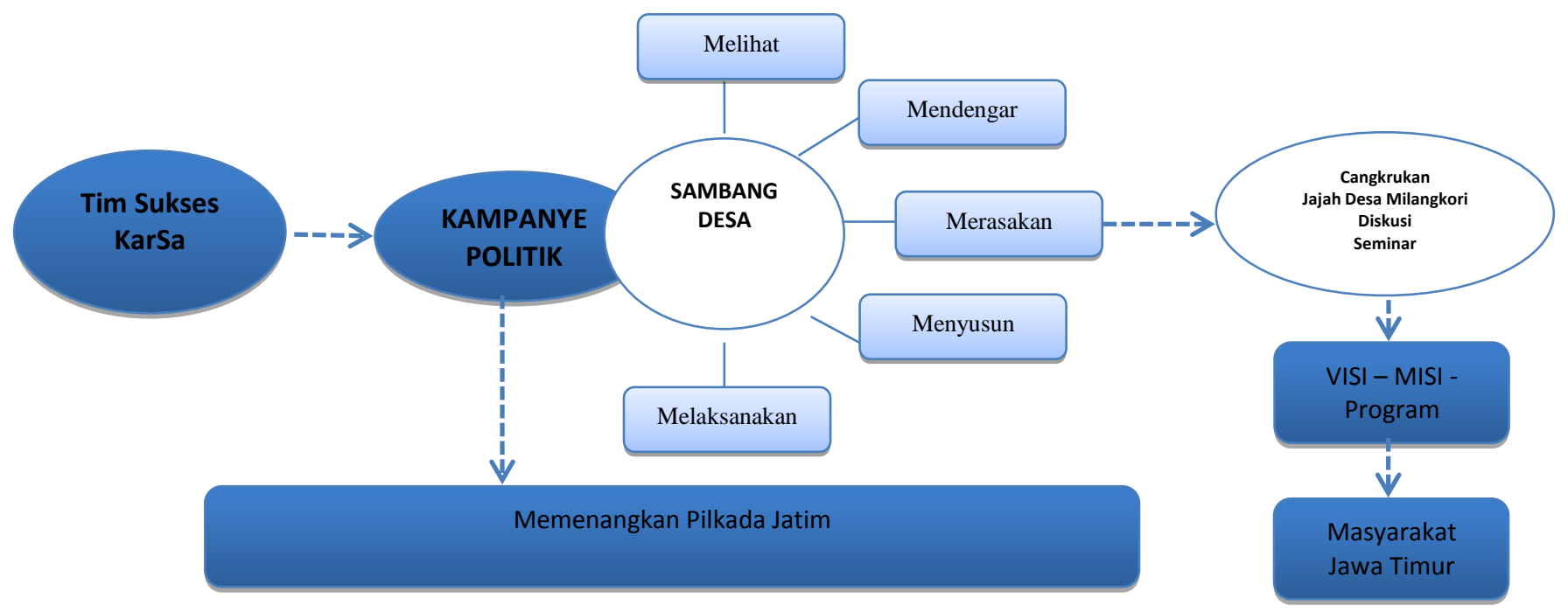

Gambar 1.

Model Pengalaman Kampanye Politik KarSa

Dari gambar di atas dapat dijelaskan bahwa pengalaman kampanye politik Tim Sukses KarSa dilakukan melalui strategi sambang desa sebagai sarana untuk berkomunikasi dengan masyarakat Jawa Timur. Visi, Misi, dan Program KarSa adalah hasil dari proses panjang yang dilakukan melalui langkah $5 \mathrm{M}$ yakni melihat, mendengar, merasakan, menyusun, dan melaksanakan. Wujud nyata strategi sambang desa dilakukan melalui berbagai kegiatan yaitu Cangkrukan, Jajah Desa Milangkori, Diskusi, dan Seminar bersama elemen masyarakat Jawa Timur.

Memenangkan pemilihan dalam setiap kompetisi politik adalah satu tujuan dari setiap calon. Namun untuk memenangkannya bukanlah sesuatu yang mudah. Diperlukan kerja keras dan strategi yang tepat agar dapat memenangkan pemilihan. Pada dasarnya proses pemenangan politik ini adalah proses bagaimana calon/kandidat suatu aktivitas politik dengan harapan mendapat respon positif dari publik/pemilu. Untuk meraih kemenangan dalam proses pemilihan, calon tidak serta merta mendapatkan dukungan dari publik. Terpilih atau tidaknya tergantung bagaimana calon (bersama tim suksesnya) "memasarkan" dirinya. Proses ini yang disebut dengan kampanye politik. Pengalaman kampanye politik KarSa melalui perjalanan yang panjang dan dilakukan secara sistematis. Persiapan dilakukan dalam kurun waktu yang panjang yakni 2-3 tahun sebelum proses pencalonan secara resmi dibuka oleh KPU. Artinya, tim sukses menyadari bahwa janji politik yang tertuang dalam visi, misi, dan program kandidat bukan sebuah persoalan yang mudah untuk dibuat, tim sukses memerlukan perencanaan yang matang dengan dasar permasalahanpermasalahan yang dihadapi oleh masyarakat Jawa Timur. 
Dalam konteks pemilu, ada dua istilah kampanye yang memiliki perbedaan arti terutama dari sisi waktu. Kampanye politik umumnya tidak terbatas pada waktu yang ditentukan. Kampanye ini dapat dimulai kapan saja calon kandidat berniat mencalonkan diri sebagai calon kandidat, saat itu juga sudah dimulai proses sosialisasi informal (kampanye politik). Sedangkan istilah yang kedua adalah kampanye pemilu. Kampanye ini dibatasi oleh aturan yang dikeluarkan oleh KPU. Berdasarkan peraturan KPU, kampanye pemilu hanya dilakukan dalam rentang waktu dua minggu saja (14 hari) sebelum masa tenang dan hari pencoblosan surat suara. Bagi politisi yang hanya memanfaatkan waktu kampanye yang diberikan KPU, tentu saja tidak akan memungkinkan untuk dapat mencapai tujuan dari kampanye. Karena hakikatnya tujuan kampanye itu bertahap, seperti halnya tahapan dalam proses komunikasi, yakni awarenessinterest-desire-action. Pada kasus calon kandidat yang belum memiliki tingkat popularitas yang cukup di masyarakat maka akan membutuhkan waktu yang relatif lama karena harus melewati semua proses tersebut. Namun bagi kandidat yang sudah memiliki popularitas dan didukung elektabilitas yang baik, maka kemungkinan untuk mempersingkat proses komunikasi tersebut.

\section{Makna Kampanye Politik KarSa}

Sedangkan hasil penelitian untuk pertanyaan kedua yakni makna kampanye politik tim sukses KarSa pada Pilkada Jawa Timur adalah sebagai berikut:

"Pengalaman berdemokrasi melalui Pemilu sudah berulang kali dialami masyarakat, namun penyelenggaraan pemilu masih belum mampu memberikan pendidikan politik yang baik. Pendidikan politik adalah suatu proses dialogis di antara pemberi pesan dan penerima pesan. Pendidikan politik tentu saja berbeda dengan indoktrinasi politik di mana yang terakhir ini merupakan proses sepihak ketika penguasa memobilisasi dan memanipulasi warga masyarakat untuk menerima nilai, norma, dan simbol yang dianggap pihak berkuasa sebagai ideal dan baik..." (Wawancara MR, 29 Juli 2016).

MR mengungkapkan bahwa dalam kampanye politik yang dilakukan harus mencerminkan pendidikan politik yang baik kepada masyarakat. Seringkali kampanye politik yang dilakukan oleh politisi menghilangkan prinsip dasar dari kampanye politik. Sedangkan TN mengatakan hal yang senada:

"Kampanye politik itu wujudnya ada banyak, ada kampanye, lobby dan negosiasi, humas, dan lain sebagainya. kampanye politik adalah sarana sosialisasi kandidat kepada masyarakat. apa saja yang direncanakan dalam kepemimpinan mendatang dituangkan dalam berbagai program melalui visi misinya. Ini penting dilakukan dan akan 
menjadi tolok ukur bagaimana masyarakat menilai kandidat tersebut..." (Wawancara TN, 25 Agustus 2016).

Menurut TS, sosialisasi melalui kampanye politik kandidat sangat penting guna memberikan informasi yang menyeluruh terkait calon pemimpin yang akan maju pada pilkada. YS juga sependapat dengan yang diungkapkan oleh YS dan DN:

"Ibaratnya itu sambang ke rakyat, kasih tahu kandidate iku sopo? dan isinya ya harus terkait bagaimana memberikan pendidikan yang baik kepada masyarakat..."(Wawancara YS, 22 September 2016).

"Kampanye itu sebuah proses yang panjang dan kalau saya bilang rumit. Dengan jangkauan wilayah yang luas, semua harus diperhitungkan. Sebagai sebuah aksi mulia, kampanye memberikan banyak informasi kandidat. pendidikan politik dimulai dari sini. bagaimana menggiring dan meyakinkan mereka bahwa pemilu ini untuk kepentingan bersama." (Wawancara DN, 29 Agustus 2016).

Informan MR memberikan makna lain dari komunikasi politik, yaitu:

"Langkah konkret yang harus
dilakukan agar dapat
menumbuhkan partisipasi
masyarakat adalah dengan
melibatkan masyarakat.
Keterlibatan ini harus dimulai
dari langkah awal penyusunan
visi, misi, dan program. Karena
itu melalui berbagai program

yang terus digalakkan sebagai sarana komunikasi dengan masyarakat, Karsa bersama tim senantiasa melibatkan masyarakat dalam proses pemilikada ini. Keputusan menggunakan Visi dan Misi 'APBD untuk Rakyat' bersama Wong cilik adalah salah satu bentuk nyata bagaimana masyarakat dilibatkan dalam proses pilkada ini. Karsa menganggap permasalahan inti negara itu ada di desa. Ketika desa itu maju, maka negara akan maju....." (Wawancara MR, 28 Januari 2016).

Sedangkan AN dan TN mengatakan bahwa kampanye politik itu adalah sebuah proses persuasi kepada masyakat melalui iklan politik:

"Nah, wujud nyata dari kegiatan kampanye politik itu dituangkan dalam iklan politik. namanya iklan ya ada proses membujuknya. Ada sentuhan kreatif yang terkadang memanipulasi sehingga diperoleh tujuan yang diinginkan..." (Wawancara AN, 10 Juli 2016).

"kita juga kasih mereka dengan uang saku atau souvenir saat ada pertemuan, ya... sebagai pengganti mereka telah meninggalkan sawah atau kebun lalu datang ke acara kami, tapi itu jangan diartikan sebagai money politic ya, jauh dari itu mbak. ungkapan rasa terima kasih saja karena sudah memberi dukungan melalui kehadirannya" (Wawancara TN, 25 Agustus 2016). 
Berdasarkan pengalaman kampanye politik dari kelima informan diatas, peneliti menemukan beberapa makna yang terkandung didalamnya.
Berikut adalah makna-makna yang ada dalam kampanye politik Tim Sukses KarSa pada Pilkada Jatim:

Tabel 2.

Makna kampanye Politik Tim Sukses KarSa pada Pilkada Jatim

\begin{tabular}{cll}
\hline Informan & \multicolumn{1}{c}{ Pengalaman informan } & \multicolumn{1}{c}{ Kategori } \\
\hline MR & Wujud demokrasi, bentuk & Makna idealis \\
& pendidikan politik & Makna idealis \\
TN & Bentuk pendidikan politik, & Makna idealis \\
& kegiatan persuasi & Makna Pragmatis \\
YS & Pendidikan politik & Makna idealis \\
AN & Kegiatan persuasi & Makna Pragmatis \\
DN & Pendidikan politik & Makna idealis \\
\hline
\end{tabular}

Sumber: Peneliti, 2017

Berdasarkan tabel diatas dapat dijelaskan bahwa peneliti menemukan dua kategori makna kampanye politik yang dilakukan oleh Tim Sukses KarSa pada Pilkada Jawa Timur yakni: idealis dan pragmatis.

Makna idealis adalah makna yang dicirikan dari kesadaran dan penilaian informan tentang pentingnya nilai-nilai ideal yang bersumber dari nilai-nilai agama dan budaya yang berlaku. Dalam penelitian ini, informan mengakui bahwa kampanye politik pada dasarnya adalah wujud dari sebuah demokrasi. Pemilihan Kepala Daerah (Pilkada) secara langsung merupakan salah satu bentuk demokrasi di level daerah. Sedangkan makna kedua adalah makna pragmatis. Makna ini dicirikan dengan kesadaran dan penilaian informan untuk mendapatkan faedah nyata dalam konteks sosial dan politik. Makna pragmatis ini diperoleh peneliti dengan melihat hasil wawancara dengan informan yang memberikan berbagai penilaian tentang faedah nyata yang diperoleh oleh informan dalam memanfaatkan peluang (melalui kampanye politik) tersebut untuk mendapatkan kepentingan-kepentingan pribadi melalui perjuangan politiknya meskipun terkadang harus mengaburkan landasan etik dan moral.

Makna idealis terdiri dari makna kampanye politik sebagai sebuah perwujudan demokrasi dan pendidikan politik kepada masyarakat. Sedangkan makna pragmatis, diwujudkan pada pemaknaan informan terhadap kampanye politik sebagai sebuah tindakan persuasi kepada masyarakat. Pertama, Kampanye adalah upaya mewujudkan demokrasi di level daerah. Dengan praktik kampanye yang baik dan sesuai dengan peraturan yang dibuat oleh KPU dan Undang-Undang yang berlaku, akan dapat mewujudkan sebuah demokrasi level lokal. Demokrasi yang diterapkan adalah demokrasi parsipatoris, yakni demokrasi 
yang berlandaskan pada partisipasi masyarakat. Hal ini ditunjukkan oleh informan dengan melibatkan berbagai elemen masyarakat terhadap proses $5 \mathrm{M}$ yang diimplementasikan melalui strategi Sambang Desa.

Kedua adalah makna pendidikan politik. Informan juga mengatakan bahwa kampanye politik KarSa merupakan upaya informan dalam melakukan pendidikan politik kepada masyarakat. Fenomena terus menurunnya partisipasi politik masyarakat menjadi alasan untuk mewujudkan makna ini. Pendidikan politik melalui kampanye politik diantaranya diwujudkan dengan sosialisasi program, visi misi KarSa, mengajak, dan mengingatkan kepada masyarakat untuk memberikan suara pada saat pencoblosan (tidak golput), dan menjadi pemilih yang rasional. Kampanye politik merupakan salah satu tahapan penting dalam pemilu di mana masyarakat diajak untuk mengenal dan memahami lebih jauh pasangan calon kandidat. Informasi yang benar terkait calon kandidat harus disampaikan sejujurnya sehingga masyarakat dapat membuat keputusan yang baik terkait calon pemimpin yang akan dipilihnya. Ketiga makna tindakan persuasi. Informan memaknai kampanye politik KarSa sebagai sebuah tindakan persuasi. Tujuan utama dari kampanye politik adalah menginformasikan ide/gagasan politik kepada masyarakat yang dituangkan dalam program dan visi misi. Melalui kampanye politik ini diharapkan masyarakat dapat mengetahui dan mengenal lebih jauh bagaimana program serta visi misi calon kandidat satu dengan yang lainnya. Karena itu, kampanye politik dikemas sebaik mungkin agar dapat menarik perhatian masyarakat sehingga menjatuhkan pilihannya kepada salah satu kandidat. Makna ini tidak menyalahi aturan yang ada, hanya dalam pelaksanaannya tindakan persuasi itu dapat diwarnai oleh berbagai kecurangan, misalnya dengan memberikan janji-janji politik yang tidak realistis, menjatuhan kandidat lain dengan memunculkan isu-isu negatif, dan lain sebagainya.

Makna tentu saja tidak muncul begitu saja dalam diri informan. Ada dorongan lain yang diberikan (baik internal maupun eksternal) yang turut memberikan pemikiran dan keyakinan kedua pasangan ini tetap mempertahankan kekuasaan yang diperolehnya. Dorongan internal dapat berasal dari hasil pemikiran diri individu yang dipengaruhi oleh faktor di dalam diri, misalnya: keinginan untuk mewujudkan tatanan sosial yang baik, keinginan membantu masyarakat pada permasalahan yang terjadi, dan idealisme yang tertanam kuat dalam diri individu serta keyakinan bahwa kepemimpinannya disukai atau kemampuan-kemampuan lain yang muncul dari dalam diri kandidat. Sedangkan dorongan eksternal berupa dorongan yang muncul di luar diri, misalnya dari keluarga, kolega, sistem sosial budaya dan lingkungan sekitarnya 
yang merupakan hasil dari interaksi sosial.

\section{KESIMPULAN}

Penelitian fenomenologis ini memberikan pembelajaran bahwa pendekatan nilai-nilai lokal masyarakat yang dilakukan melalui strategi sambang desa menjadi strategi efektif dalam sebuah kampanye politik. Pengalaman dan proses kampanye yang dialami oleh informan penelitian terdiri dari beberapa tema yakni tema sebagai perwujudan demokrasi, pendidikan politik dan kegiatan persuasi. Diantara tema tersebut mengandung dua makna yakni makna idealis dan pragmatis. Kedua makna ini merupakan sebuah proses politik sebagai upaya mencapai tujuan politik, yakni memenangkan pilkada Jawa Timur. Dalam konteks pilkada, kampanye politik adalah salah satu bagian dari proses politik yang melibatkan banyak elemen yang memiliki kepentingan yang berbeda. Proses politik ini terjadi dalam interaksi sosial.

\section{DAFTAR PUSTAKA}

Agustino. 2009. Pilkada dan Dinamika Politik Lokal. Yogyakarta: Pustaka Pelajar.

Arifin, Anwar. 2003. Komunikasi Politik dan Sistem Politik Indonesia, Jakarta: Gramedia.

Audrey, A. Haynes, dkk. 2009, Going Negative: Press Responses to
Candidate Attack Messages. Journal of Political Marketing. 8: 81 - 104. Book 1. Roudledge: Taylor \& Francis Group.

Bogdan and Steven J. Taylor. 1992. Introduction to Qualitative Research Methods: A Phenomenological Approach in the Social Science, Alih Bahasa Arief Furchan, Surabaya: John Willey and Sons.

Chaffee, Steven H dan Albert R. Tim. 1982. Political Communication: Issues and Strategies for Research. Belmont, CA: Sage Publication.

Chris Rudd. 2005. Marketing The Message or The Messanger?, Journal Political Marketing A Comparative Perspective. Manchester University Press.

Grey, Judge Lawrence. 1994. How to Win A Local Election. Ney York: E. Evans and Company Inc.

Firmanzah. 2008. Marketing Politik: Antara Pemahaman dan Realitas. Jakarta: Yayasan Obor Indonesia.

Holtz, Christina \& Bacha. 2004. Political Campaign Communication. Journal Communication, Society and Politics, Cambridge University Press.

Kaid, Lyda Lee. 2004. Handbook of Political Communication Research. New Jersey: Lawrence Erlbaum Associates.

Lilleker, Darren G. 2006. Key Concepts in Political Communications. New Delhi: Sage Publications.

Nimmo, Dan 2004. Komunikasi Politik. Bandung: Remaja Rosdakarya.

Pawito, P. 2009. Komunikasi Politik Media Massa dan Kampanye Pemilihan. Yogyakarta: Jalasutra. 
Rice. R.E \& W.J. Paisley. 1981. Public Communication Campaigns. London: Sage Publications. Ltd.

Trent Judith S, Robert V. Frieerberg. 2008. Political Campaign Communication: Principles and Practices, Rowman \& Littlefield.

Venus, Antar. 2009. Manajemen Kampanye. Bandung: Simbiosa Rektama.

Wahyudi, Hari. 2015. Tim Sukses Dramaturgi Pemasaran Pak De Karwo, Sidoarjo: Dwiputra Pustaka Jaya.

Wayne, P. Steger dkk. 2006. Campaigns and Political Marketing in Political Science Context. Journal of Political
Marketing, Vol. 5 Number $1 / 2$. The Haworth Press, Inc. 